\title{
Vertical Distribution of Micronutrient Cations in Imphal East and West District, Manipur (India)
}

\author{
Herojit Singh Athokpam*, Khuraijam Surmani Singh, Nandini Chongtham, \\ K. Nandini Devi, Naorem Brajendra Singh, Athokpam Sanatomba and P.T. Sharma \\ College of Agriculture, Central Agricultural University, Imphal - 795004, India \\ *Corresponding author
}

Keywords

DTPA,

Micronutrient cations, Paddy Field, Profile

Article Info

Accepted:

22 July 2018

Available Online:

10 August 2018

\section{A B S T R A C T}

Vertical distribution of DTPA-extractable micronutrient cations $(\mathrm{Zn}, \mathrm{Cu}, \mathrm{Fe}$ and $\mathrm{Mn})$ and their relationship with various soil properties were studied in thirty profiles of paddy field of Imphal east and west district of Manipur. The content of DTPA-extractable $\mathrm{Zn}, \mathrm{Cu}, \mathrm{Fe}$ and Mn were higher in surface $(0-20 \mathrm{~cm})$ horizons and decreased with depth in most of the profiles and ranged from 0.14 to $2.48,0.26$ to $1.26,1.96$ to 21.46 and 2.00 to $24.20 \mathrm{mg}$ $\mathrm{Kg}^{-1}$, respectively. DTPA-extractable $\mathrm{Zn}$ was found deficient in 75.56 per cent and sufficient in 22.44 per cent in the soil samples, $\mathrm{Cu}$ was found in 81.11 per cent sufficient and 18.89 in deficient and $\mathrm{Mn} 86.67$ per cent was found sufficient and 13.33 per cent in deficient category, While $\mathrm{Fe}$ content in the surface soils were well sufficient in all the profile except one profile. Distribution of $\mathrm{Zn}, \mathrm{Cu}, \mathrm{Mn}$ and $\mathrm{Fe}$ were influenced positively by $\mathrm{OC}, \mathrm{CEC}, \mathrm{EC}, \mathrm{Ca}, \mathrm{Mg}$ and $\mathrm{N}$ content in the soil. Multiple regression co-efficient analysis showed that DTPA-extractable $\mathrm{Zn}, \mathrm{Cu}, \mathrm{Fe}$ and $\mathrm{Mn}$ were influenced by $\mathrm{OC}, \mathrm{K}$ and $\mathrm{N}$ to the level of 44, 40, 21 and 40 per cent, respectively. However, only OC, K and N contributed significantly towards these nutrient cations content in the soils.

\section{Introduction}

Micronutrients play various important role in plant is well established. It plays an active role in plant metabolism i.e. cell wall development, respiration, photosynthesis, chlorophyll formation, enzyme activity, hormone synthesis, atmospheric nitrogen fixation, etc. The requirement of micronutrients for crop plants are relatively very small, however, if any deficiencies of it, the crop yield is drastically reduced. Micronutrients are very important for maintaining soil health and also increasing productivity of crops (Rattan et. al. 2009). However, exploitive nature of modern agriculture involving use of high analysis NPK fertilizers couple with limited use of organic manure and less recycling of crop residues are important factors contributing towards accelerated exhaustion of micronutrients from the soil (Sharma and Choudhary, 2007). Continuous negligence of micronutrient application and avoidance of organic manures are the major causes of 
deficiency of these micronutrients (Srivastava et al., 2017). Thus, the deficiency of micronutrients has become a major constraint to productivity and sustainability in many Indian soils. The availability of micronutrients to plants is also influenced by the distribution within the soil profile (Singh and Dhankar, 1989). The knowledge of vertical distribution of micronutrients is important as roots of many plants go beyond the surface layer and thus draw a part of the nutrient requirement from the subsurface layers of the soils. The distribution of micronutrient cations of paddy fields of Imphal east and west district of Manipur was not yet studied. Therefore, the present work has been undertaken to assess the distribution of micronutrient cations of the paddy fields and to find out the relationship between the soil properties and micronutrients.

\section{Materials and Methods}

Typical thirty soil profiles were exposed and depth wise i.e. 0-20, 20-40 and 40-60 cm soil samples were collected. All the soil samples were air-dried, ground and passed through 2 $\mathrm{mm}$ sieve for physico-chemical analysis like soil texture, $\mathrm{pH}, \mathrm{EC},(1: 2.5$ soil: water), organic carbon, CEC, available $\mathrm{N}, \mathrm{P}$ and $\mathrm{K}$, $\mathrm{Ca}$ and $\mathrm{Mg}$ using standard laboratory procedures outline by Borah et al., (1987), Chopra and Kamwar (1976), Jackson (1973), Subbiah and Asija (1956) and Walkley and Black (1934).

The DTPA-extractable $\mathrm{Zn}, \mathrm{Cu}, \mathrm{Fe}$ and $\mathrm{Mn}$ in the soil samples were extracted with a solution of $0.005 \mathrm{M}$ DTPA, $0.01 \mathrm{M} \mathrm{CaCl}_{2}$ and $0.1 \mathrm{M}$ triethanolamine adjusted to $\mathrm{pH} 7.3$ as outlined by Lindsay and Norvell (1978). The concentration of micronutrient cations in the extract was determined using atomic absorption spectrophotometer. Multiple regression equations were computed between DTPA-extractable micronutrients and soil properties was done by adopting statistical procedures (Panse and Sukhatme, 1961).

\section{Results and Discussion}

The relevant soil characteristics of the representative soil profiles are describe in table 1 . There were no definite pattern found in the distribution of sand, silt, and clay content in the profile. Sand content varied from 10.4 to 28.8 per cent, silt ranged from 15.0 to 25.0 per cent and clay contents were varied from 57.1 to 86.2 percent. The soils were strongly acidic $(\mathrm{pH} 4.21-5.34)$. The EC ranges from 0.01 to $0.21 \mathrm{dSm}^{-1}$ and organic carbon content from 0.60 to 3.0 per cent. Surface soil layers content more organic carbon than the sub-surface layers. CEC ranged from 10.0 to $24.0\left[\mathrm{cmol}\left(\mathrm{p}^{+}\right)\right] \mathrm{kg}^{-1}$ soil. The exchangeable $\mathrm{Ca}$ and $\mathrm{Mg}$ content in the soils varied from 0.46 to 6.03 and 0.46 to 4.60 $\left[\mathrm{cmol}\left(\mathrm{p}^{+}\right)\right] \mathrm{kg}^{-1}$ soil, respectively, both bases decreased with increased in depth in all the soil profiles. The available $\mathrm{N}, \mathrm{P}$ and $\mathrm{K}$ content in the soils were 118.16 to $344.96,3.14$ to

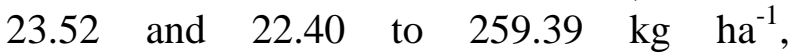
respectively. These nutrients content decreased with increased the depth in the soil profile.

\section{DTPA-extractable micronutrients status}

Zinc: DTPA-extractable $\mathrm{Zn}$ in the studied soil profiles varied from 0.04 to $2.48 \mathrm{mg} \mathrm{kg}^{-1}$ in the paddy fields of Imphal east and west district of Manipur. Sen et al., (1997) reported the available $\mathrm{Zn}$ content vary from 0.2 to 1.4 $\mathrm{mg} \mathrm{kg}^{-1}$ and decreased down the profile. Similar observations were also reported by Athokpam et al., (2013) and Athokpam et al., (2016) and Athokpam et al., (2018). Considering $0.6 \mathrm{mg} \mathrm{kg}^{-1}$ as the critical limit of available $\mathrm{Zn}$ as suggested by Takkar and Mann (1975), $\mathrm{Zn}$ was found deficient in 75.56 per cent and sufficient in 22.44 per cent in the soil samples. DTPA-extractable $\mathrm{Zn}$ showed non-significant regression with soil properties in the surface layer $(0-20 \mathrm{~cm})$ and subsurface layer $(40-60 \mathrm{~cm})$ as evident from the data in table 2. 
Table.1 Some physico-chemical properties of the soils

\begin{tabular}{|c|c|c|c|}
\hline Soil properties & Soil depth & Range & mean \\
\hline Sand (\%) & - & $10.4-28.8$ & - \\
\hline Silt $(\%)$ & - & $15.0-25.0$ & - \\
\hline Clay (\%) & - & $57.1-86.2$ & - \\
\hline pH & $\begin{array}{l}0-20 \\
20-40 \\
40-60\end{array}$ & $\begin{array}{l}4.56-5.12 \\
4.21-5.21 \\
4.40-5.34\end{array}$ & $\begin{array}{l}4.75 \\
4.79 \\
4.87\end{array}$ \\
\hline $\mathrm{EC}\left(\mathrm{dSm}^{-1}\right)$ & $\begin{array}{l}0-20 \\
20-40 \\
40-60\end{array}$ & $\begin{array}{l}0.04-0.21 \\
0.02-0.16 \\
0.01-0.10\end{array}$ & $\begin{array}{l}0.096 \\
0.067 \\
0.034\end{array}$ \\
\hline $\operatorname{CEC}\left[\operatorname{cmol}\left(p^{+}\right)\right] \mathrm{kg}^{-1}$ & $\begin{array}{l}0-20 \\
20-40 \\
40-60\end{array}$ & $\begin{array}{l}14.0-24.0 \\
10.0-22.2 \\
11.2-20.1\end{array}$ & $\begin{array}{l}17.75 \\
16.09 \\
14.74\end{array}$ \\
\hline $\mathrm{Ca}\left[\operatorname{cmol}\left(\mathrm{p}^{+}\right)\right] \mathrm{kg}^{-1}$ & $\begin{array}{l}0-20 \\
20-40 \\
40-60\end{array}$ & $\begin{array}{l}0.89-6.03 \\
0.46-4.21 \\
0.73-3.06 \\
\end{array}$ & $\begin{array}{l}2.22 \\
2.17 \\
1.36\end{array}$ \\
\hline $\operatorname{Mg}\left[\operatorname{cmol}\left(p^{+}\right)\right] k^{-1}$ & $\begin{array}{l}0-20 \\
20-40 \\
40-60\end{array}$ & $\begin{array}{l}1.15-4.60 \\
0.78-3.86 \\
0.46-3.50\end{array}$ & $\begin{array}{l}3.10 \\
2.33 \\
1.49\end{array}$ \\
\hline $\begin{array}{l}\text { OC } \\
(\%)\end{array}$ & $\begin{array}{l}0-20 \\
20-40 \\
40-60\end{array}$ & $\begin{array}{l}1.20-3.00 \\
0.76-2.70 \\
0.60-1.80\end{array}$ & $\begin{array}{l}1.72 \\
1.41 \\
1.10\end{array}$ \\
\hline$N\left(\right.$ kg ha $\left.^{-1}\right)$ & $\begin{array}{l}0-20 \\
20-40 \\
40-60\end{array}$ & $\begin{array}{l}219.50-344.96 \\
188.16-282.24 \\
188.16-250.88\end{array}$ & $\begin{array}{l}264.55 \\
241.47 \\
204.64 \\
\end{array}$ \\
\hline$P\left(\right.$ kg ha $\left.^{-1}\right)$ & $\begin{array}{l}0-20 \\
20-40 \\
40-60\end{array}$ & $\begin{array}{l}6.27-23.52 \\
4.60-18.81 \\
3.14-15.68\end{array}$ & $\begin{array}{l}15.89 \\
12.32 \\
8.35 \\
\end{array}$ \\
\hline$K\left(\mathrm{~kg} \mathrm{ha}^{-1}\right)$ & $\begin{array}{l}0-20 \\
20-40 \\
40-60\end{array}$ & $\begin{array}{l}55.78-259.39 \\
51.97-157.02 \\
22.40-112.00\end{array}$ & $\begin{array}{l}142.99 \\
103.53 \\
65.89\end{array}$ \\
\hline $\mathrm{Zn}\left(\mathrm{mg} \mathrm{kg}^{-1}\right)$ & $\begin{array}{l}0-20 \\
20-40 \\
40-60\end{array}$ & $\begin{array}{l}0.14-2.48 \\
0.10-1.12 \\
0.04-1.00\end{array}$ & $\begin{array}{l}0.69 \\
0.40 \\
0.22\end{array}$ \\
\hline $\mathrm{Cu}\left(\mathrm{mg} \mathrm{kg}{ }^{-1}\right)$ & $\begin{array}{l}0-20 \\
20-40 \\
40-60\end{array}$ & $\begin{array}{l}0.26-1.26 \\
0.12-1.22 \\
0.06-1.22\end{array}$ & $\begin{array}{l}0.48 \\
0.38 \\
0.29\end{array}$ \\
\hline $\operatorname{Mn}\left(\mathrm{mg} \mathrm{kg}^{-1}\right)$ & $\begin{array}{l}0-20 \\
20-40 \\
40-60\end{array}$ & $\begin{array}{l}1.96-21.46 \\
0.58-23.40 \\
0.12-4.56\end{array}$ & $\begin{array}{l}9.86 \\
5.25 \\
2.04\end{array}$ \\
\hline $\mathrm{Fe}\left(\mathrm{mg} \mathrm{kg}^{-1}\right)$ & $\begin{array}{l}0-20 \\
20-40 \\
40-60\end{array}$ & $\begin{array}{l}2.00-24.20 \\
1.64-21.40 \\
0.22-13.08\end{array}$ & $\begin{array}{l}13.76 \\
7.58 \\
4.64\end{array}$ \\
\hline
\end{tabular}


Table.2 Effect of soil characteristics on predictability of micronutrient cations

\begin{tabular}{|c|c|c|}
\hline Micronutrients & Equations & $\mathbf{R}^{2} \times 100$ \\
\hline $\begin{array}{l}\text { Zn } \\
\begin{array}{l}0-20 \mathrm{~cm} \\
20-40 \mathrm{~cm} \\
40-60 \mathrm{~cm}\end{array}\end{array}$ & $\begin{array}{l}=-0.013+0.136 \mathrm{Ca}-0.088 \mathrm{Mg} \\
=1.797-0.315 \mathrm{pH}+0.210 * \mathrm{OC}-0.002 * \mathrm{~K} \\
=-0.230+0.004 \mathrm{CEC}+0.278 \mathrm{OC}-0.001\end{array}$ & $\begin{array}{l}28.5^{*} \\
43.8^{*} \\
27.6^{*}\end{array}$ \\
\hline $\begin{array}{l}\text { Cu } \\
\quad 0-20 \mathrm{~cm} \\
20-40 \mathrm{~cm} \\
40-60 \mathrm{~cm}\end{array}$ & $\begin{array}{l}=-0.191+1.518 \mathrm{EC}-0.011 \mathrm{CEC}+0.242 \mathrm{OC}+ \\
0.001 \mathrm{~N} \\
=-0.042+0.019 \mathrm{CEC}+0.214 \mathrm{OC}-0.001 \mathrm{~N} \\
=-0.254+0.019 \mathrm{CEC}+0.233\end{array}$ & $\begin{array}{l}39.6^{*} \\
25.0 \\
19.9^{*}\end{array}$ \\
\hline $\begin{array}{l}\text { Mn } \\
\quad 0-20 \mathrm{~cm}\end{array}$ & $=-6.037+0.046 \mathrm{~N}+1.061 \mathrm{Ca}$ & $20.7 *$ \\
\hline $\begin{array}{l}\text { Fe } \\
\qquad \begin{array}{l}0-20 \mathrm{~cm} \\
20-40 \mathrm{~cm}\end{array}\end{array}$ & $\begin{array}{l}=-37.377+0.307 \mathrm{CEC}-8.838 \mathrm{OC}+0.201 * \mathrm{~N}+ \\
0.363 \mathrm{P} \\
=-10.303+3.191 \mathrm{OC}+0.055 \mathrm{~N}\end{array}$ & $\begin{array}{l}40.1 * * \\
20.2^{*}\end{array}$ \\
\hline
\end{tabular}

The multiple regression equations presented in the table 2 indicate a predictability value of 28.5 per cent by all factors taken together in the $1^{\text {st }}$ layer. Significant regression with OC $(0.210 *)$ and $\mathrm{K}(0.002 *)$ in the $2^{\text {nd }}$ layer $(20-$ $40 \mathrm{~cm})$ and $3^{\text {rd }}$ layer $(40-60 \mathrm{~cm})$ and their predictability were 43.8 and 27.6 per cent, respectively.

Copper: DTPA-extractable $\mathrm{Cu}$ content in the profiles ranged from 0.06 to $1.26 \mathrm{mg} \mathrm{kg}^{-1}$. Out of the thirty profiles, DTPA-extractable $\mathrm{Cu}$ content in the soils, 81.11 per cent sufficient and 18.89 in deficient, is being $0.2 \mathrm{mg} \mathrm{kg}^{-1}$ as critical value (Lindsay and Norvell, 1978). DTPA-extractable $\mathrm{Cu}$ content was higher in the surface soils and decreased gradually in all the profiles. Similar results were also reported by Gupta et al., (2003), Verma et al., (2007), Athokpam et al., (2016) and Athokpam et al., (2018). The multiple correlation and regression analyses indicated that the $\mathrm{Cu}$ content was influenced by EC, CEC, OC, and N, however, their influenced were not significant. Their predictability was 39.6, 25.0 and 19.9 per cent variability by all factors taken together in the $1^{\text {st }}, 2^{\text {nd }}$ and $3^{\text {rd }}$ layers in the profiles, respectively.
Iron: DTPA-extractable Fe content in the profiles ranged from 0.22 to $24.20 \mathrm{mg} \mathrm{kg}^{-1}$ and are comparable with those reported by Gupta et al., (2003), Sharma and Choudhary (2007) in the soils of Madhya Pradesh and north-west Himalaya (H.P.) and Athokpam et al.,(2016), respectively. Almost all the surface soils had sufficient amounts of available Fe, except one profile, considering $4.5 \mathrm{mg} \mathrm{kg}^{-1}$ as critical limit (Lindsay and Norvell, 1978). Surface soils content more available Fe than the sub-surface soils. It showed significant regression coefficient with $\mathrm{N}(0.201 *)$ in the $1^{\text {st }}$ layer. Multiple correlation and regression analyses indicated that 40.1 and 20.2 per cent variability in the DTPA-extractable Fe in the profiles was due to the combine effect of CEC, OC, $\mathrm{N}$ and $\mathrm{P}$ in the soils.

Manganese: DTPA-extractable $\mathrm{Mn}$ in the profiles varied from 0.12 to $23.40 \mathrm{mg} \mathrm{kg}^{-1}$ with a mean value of $5.72 \mathrm{mg} \mathrm{kg}$. The surface soils content higher Mn and decreased with increased in depth (Gupta et al., (2003), Verma et al., (2007), Athokpam et al., (2016) and Athokpam et al., (2018). Considering the critical limit of $1.0 \mathrm{mg} \mathrm{kg}^{-1}$ (Lindsay and 
Norvell, 1978), the surface soils were well above the critical limits. Multiple correlation and regression analyses indicated that 20.7 per cent variability of the available $\mathrm{Mn}$ content could be attributed to the combine effect of $\mathrm{N}$ and $\mathrm{Ca}$ content in the profiles but their effect is not significant.

The variations in the available micronutrients among and within the profiles might be the result of variable intensity of different pedogenic processes taking place during the soil development. The surface layers contained higher amounts of available $\mathrm{Zn}, \mathrm{Cu}$, $\mathrm{Fe}$ and $\mathrm{Mn}$ which progressively declined with depth in all the soil profiles. Similar distribution pattern of micronutrients within the profiles was also reported by Sharma et al., (1999) and Sharma and Choudhary (2007), Athokpam et al., (2016) and Athokpam et al., (2018). This may be ascribed to low $\mathrm{pH}$ values and higher amounts of organic carbon content in the surface soils. Decomposition of organic matter releases micronutrients and some organic acids which in turn help in increasing solubility of micronutrients from the soil mineral. Significant positive regression coefficients of EC with DTPA-extractable micronutrients have also been reported by Randhawa and Singh (1995) and Sharma et al., (2006).

\section{References}

Athokpam, H., Wani, S.H., Kamei, D., Athokpam, H.S., Nongmaithem, J., Kumar, D., singh, Y.K., Naorem, B.S, Devi, T.R. and Devi, L. (2013). Soil macro and micro-nutrient status of Senapati district, Manipur (India). African Journal of Agricultural Research.8(39):4932-4936.

Athokpam, H.S., Zimik, V.S., Chongtham, N., Devi, K.N., Singh, N.B., Watham, L., Sharma, P.T. and Athokpam, H. (2016). Profile distribution of micronutrient cations in citrus orchard of Ukhrul district, Manipur (India). International Journal of Agriculture, Environment and Biotechnology. 9(4): 691-697.

Athokpam, H.S., Vikramjeet, K., Chongtham, N., Devi, K.N., Singh, N.B., Singh, N.G., Sharma, P.T. and Heisnam, P. (2018). Micronutrient cations distribution in the soil profile of orange (Citrus reticulate) orchards of Tamenglong district, Manipur (India). Journal of Experimental Biology and Agricultural Sciences. 6(1): 108-115.

Borah, D.K., Bordoloi, P.K., Karmakar, R.M., Baruah, N.G. and Das, M. 1987. Practical Manual of Fundamental of Soil Science (Part-III), Jorhat, Assam.

Chopra, S.L. and Kanwar, J. 1976. Analytical Agricultural Chemistry. Kalayani Publisher. Ludhiana, New Delhi.

Gupta, N., Trivedi, S.K., Bansali, K.N. and Kaul, R.K. 2003. Vertical distribution of micronutrient cations in some soil series of north Madhya Pradesh. Journal of the Indian Society of Soil Science. 51: 517-522.

Jackson, M.L. 1973. Soil Chemical Analysis. Prentice Hall of India Pvt. Ltd., New Delhi.

Lindsay, W.L. and Norvell, W.A. 1978. Development of DTPA soil test for $\mathrm{Zn}, \mathrm{Fe}, \mathrm{Mn}$ and $\mathrm{Cu}$. Soil Science Society of America Journal. 42: 421428.

Panse, V.G. and Sukhatme, P.V. 1961. Statistical Methods for Agricultural Workers, ICAR, New Delhi.

Rattan, R.K., Patel, KP., Manjaiah, KM. and Datta, SP. 2009. Micronutrients in soil, plant, animal and human health. Journal of the Indian Society of Soil Science. 57:546-558.

Randhawa, H.S. and Singh, P. 1995. Distribution of zinc fractions in alluvium derived soils of Punjab. 
Journal of the Indian Society of Soil Science. 43:124-126.

Sen, T.K., Dubey, P.N., Maji, A.K. and Chamuah, G.S. 1997. Status of micronutrients in some dominant soils of Manipur. Journal of the Indian Society of Soil Science. 45:388-390.

Sharma J.C. and Choudhary, S.K. 2007. Vertical distribution of micronutrient cations in relation to soil characteristics in lower Shiwaliks of Solan district in north-west Himalayas. Journal of the Indian Society of Soil Science. 55:40-44.

Sharma, B.D., Jassal, H.S., Swahney, J.S. and Sidhu, P.S. 1999. Micronutrient distribution in different physiographic unit of Siwalik hills of semiarid tract of Punjap. Arid Soil Research and Rehabilitation. 13:189-200.

Sharma, V.K., Sanjai, K., Dwivedi, Tripathi, D. and Ahmed, Z. 2006. Status of available major and micronutrients in the soil of different blocks of Leh district of cold arid region of Ladakh in relation to soil characteristics. Journal of the Indian Society of Soil Science. 54: 248-250.

Singh, K.M.S. and Dhankar, S.S. 1989. Influence of soil characteristics on profile distribution of DTPAextractable micronutrient cations.
Indian Journal of Agricultural Sciences. 59:331-334.

Srivastava, P.P., Pandiaraj, T., das, S. and Sinha, A.K. 2017. Assessment of micronutrient status of soil under Tasar host plant growing regions in Jashpur district, Chhattisgarh State. Imperial Journal of Interdisciplinary Research. 3: 1080-1083.

Subbiah, B.V. and Asija, G.L. 1956. A rapid procedure for estimation of available $\mathrm{N}$ in soils. Current Science. 25: 259260.

Takkar, PN. and Mann, MS. 1975. Evaluation of analytical methods of estimation of available zinc and response of applied zinc in major soil series of Ludhiana, Punjab. Agrochemica.19:420-430.

Verma, V.K., Setia, R.K., Sharma, P.K., Khurana, M.P.S. and Kang, G.S. 2007. Pedopheric distribution of micronutrient cations in soil developed on various landforms in north-east Punjab. Journal of the Indian Society of Soil Science. 55:515-520.

Walkley, A. and Black, I.A. 1934. An examination of the Degtjareff method determining soil organic matter and a proposed modification of the chromic acid titration method. Soil Science. 34: 29-38.

\section{How to cite this article:}

Herojit Singh Athokpam, Khuraijam Surmani Singh, Nandini Chongtham, K. Nandini Devi, Naorem Brajendra Singh, Athokpam Sanatomba and Sharma, P.T. 2018. Vertical Distribution of Micronutrient Cations in Imphal East and West District, Manipur (India). Int.J.Curr.Microbiol.App.Sci. 7(08): 4222-4227. doi: https://doi.org/10.20546/ijcmas.2018.708.442 